\title{
Tax-Benefits Reforms and the Labor Market: Evidence from Belgium and other EU Countries*
}

\author{
Kristian Orsini (KU Leuven)
}

\author{
Working Paper
}

This Draft: March 22, 2006

\begin{abstract}
During the last decade, several EU countries have tried to tackle unemployment and low activity rates through extensive tax cuts. In an effort to encourage the taking up of work - especially amongst the less productive workers - policymakers have shown increasing interest in targeted tax and social security contribution rebates as well as in benefits conditional on being in employment. This paper surveys recent tax-benefit reforms in Germany, the Netherlands, Italy, The UK, France and Belgium, focussing in particular on the reforms carried out in the latter. The potential labor supply effect of the Belgian reforms are assessed via a discrete hours labor supply model. The results are then compared to similar evaluations of reforms implemented in the aforementioned countries. Results suggest that: (i) generalized tax cut are not always effective in stimulating labor supply; (ii) in several central continental Europe, social security contributions play a major role in determining the incentives to take up work; (iii) joint assessment of income for both purposes of taxation and benefit eligibility has unambiguous negative effects on the labor supply of secondary earners (i.e. mostly women); (iv) targeted reductions in taxes and social security contributions, as well as benefits conditioned on employment are effective means to promote employment, but (v) efficient design of these policies is of greatest importance in order to counter potential negative incentive effects on the population already in employment.
\end{abstract}

Keywords: Tax-benefit Systems - Microsimulation - Household Labour Supply - Multinomial Logit.

JEL Classification: D31, H21, H23, H24, H31, J22.

*The author thanks Olivier Bargain, Ugo Colombino, Marcel Das, André Decoster, Jérôme Dehenau, Peter Haan, Sile O'Dorchai, Christian Valenduc, Kris Van Couter, Arthur Van Soest, Katharina Wrohlich and the participants of the BENA, CES and DULBEA seminars, as well as the participants of the seminar held at the Belgian Institute of Public Finance for helpful comments and suggestions. This paper was written as part of the MICRESA (Micro Analysis of the European Social Agenda) project, financed by the Improving Human Potential programme of the European Commission (SERD-2001-00099). I am grateful to the PSBH team at the University of Liége and University of Antwerpen for support with the PSBH data. The usual disclaimer applies. Correspondence: Kristian Orsini, CESKUL, Naamsestraat 69, Leuven, 3000 Belgium. Email: kristian.orsini@econ.kuleuven.be 


\section{Introduction}

Recent cross-country empirical studies on the potential negative effects of the tax burden on employment have been surveyed by De Haan, Sturm, and Volkerink (2003). They conclude that, although the overall effect of the tax wedge is probably smaller than earlier estimates, its effects are greater in continental European countries, due to an intermediate level of labor market centralization.

Particularly harmful are the effects of heavy taxation on the employment level of low skilled workers (Layard and Nickell, 1999). This holds also for Belgium, where the low skilled employment rate lies just above $55 \%$. In the case of women, and even more so women in couples, the picture is particularly dramatic. According to Labor Force Statistics slightly less than $40 \%$ of married women with less than secondary education are in employment.

Employment policy in Continental Europe and in Belgium has traditionally been focused on demand side measures, probably due to the heavy process of industrial restructuring. In recent years, however, several EU countries have tried to tackle the inactivity trap from a labor supply perspective. Starting from 1999 the Belgian federal government has taken major steps towards the reduction of the tax burden on labor. The first measure was the introduction of substantial reductions in employees' Social Security Contributions (SSC) for low paid workers. In a second step the government has passed a bill for the progressive abolition of the Contribution Complémentaire de Crise (CCC), an additional surcharge that had been introduced during the tough budgetary crisis of the early $90 \mathrm{~s}$.

In 2001 the Belgian parliament passed a bill to reform of the personal income tax, ${ }^{1}$ which included a refundable tax credit on low earnings and a generalized reduction of the tax burden. The reform was estimated to have a budgetary cost of 3.33 billion EUR, which corresponded to a decrease in tax revenue of almost $10 \%$.

In year 2004, a year before full implementation of the tax reform, a second reform amended some aspects of the tax regime. In particular, the newly introduced tax credit on low earnings was replaced by a substantial decrease in low skilled employees' SSC.

This paper describes the recent Belgian reforms and evaluates their potential impact on labor supply. At the same time it compares the Belgian experience to those of several other EU countries (namely the UK, Germany, France, Italy and the Netherlands) that have recently introduced (or planned) significant reforms in their tax-benefit systems.

Consistently with evaluations of the reforms in the above countries, we develop a discrete-hours labor supply model. Such models assume that there are no feedback effects due to the interaction of labor supply and demand and neglect the potential effects of involuntary unemployment. ${ }^{2}$

\footnotetext{
${ }^{1}$ De Callataÿ (2002) argues that the term 'tax reform' is partially misleading given the substantial continuity of the new tax code with the previous one, and prefers the term 'tax reduction'.

${ }^{2}$ Neglecting the latter may indeed lead to severe bias in the estimate of labor supply elasticities, while aggregated behavioral effects tend to be overestimated Bargain, Caliendo, Haan, and Orsini (2005). It might be argued, however, that neglecting involuntary unemployment as well as potential feedback effects leads to upper bound estimates of the behavioral adjustments. Note that one of the surveyed papers (Aaberge, Colombino, and Strøm, 2004) controls for involuntary unemployment.
} 
The structure of the paper is as follows: section 2 will summarize recent reforms in the EU countries, section 3 will introduce the recent reforms implemented in Belgium, section 4 presents the methodological framework; section 5 overviews empirical findings related to reforms in Germany, in the Netherlands, in Italy, in the UK and in France; section 6 analyzes the potential impact of the Belgian reforms and section 7 concludes.

\section{Tax-benefit reforms in the EU}

The withdrawal of means-tested social assistance benefits or unemployment benefits, coupled with heavy taxation of earned income and fixed costs of labor supply, significantly reduces the incentives to take up paid work, generating, especially for the less productive workers, inactivity and poverty traps. $^{3}$

The situation is particularly dramatic in continental Europe which heavily depends on a high wage strategy. The Bismarkian welfare state is in fact characterized by relatively high social security contribution and generous insurance based transfers, while labor markets are relatively sticky given the rigidly structured industrial relations.

The fact that labor market performance of less skilled workers has been particularly poor in these countries is confirmed by a recent study of Daveri and Tabellini (2000). The authors argue that the heavy burden in terms of labor costs, combined with an intermediate degree of labor market centralization is the main cause of persisting poor employment performances.

Reforms introduced in EU Member States in the past 10 years have aimed at stimulating employment by reforming their tax and benefit systems. ${ }^{4}$

The reforms have followed two major axes: on the one side, they have aimed at a generalized reduction of the tax burden (especially on labor), and on the other they have introduced more or less generous schemes aiming at increasing the income of the working poor. 'In-work' tax credits, subsidized social security contributions and employment conditional transfers all fall into the second group of measures, generally referred to as Making Work Pay (MWP) policies. ${ }^{5}$

In the US, where such instruments were first introduced, the transfers were assigned via a tax credit on earned income. In the UK, the transfer was originally a means tested benefit for which poor working households could apply. A peculiarity of most Continental European countries is the contribution financed and insurance based social security. Contribution rates tend to be extremely high even on very low earnings. Next to refundable tax credits and employment conditional

\footnotetext{
${ }^{3}$ For a detailed discussion of inactivity and poverty traps at the European level, see Périvier (2003).

${ }^{4}$ We here review only the main reforms implemented (or planned) in the most recent years. Radical reforms were introduced earlier in the 90s in Scandinavian countries, while minor reforms were implemented in Austria and Spain. For a detailed review of these reforms, see Sterdyniak (2003) and Bernardi and Profeta (2004).

${ }^{5}$ MWP policies have been proposed as hybrid instruments designed to reshape the link between employment, solidarity and social justice in the new century's welfare state. Given their hybrid nature, it should not come as a surprise that at least two broad motivations may be put forward to justify their implementation (Pearson and Scarpetta, 2000): (i) economic inclusion, i.e. the economic mainstreaming of society's most vulnerable individuals, with positive feedbacks coming from decreased spending on income maintenance and poverty related social problems like poor health or crime; (ii) redistribution, i.e. increasing the financial resources of the weakest fraction of the population, with positive feedbacks coming from increased social cohesion.
} 
benefits, some EU countries have therefore introduced rebates on social security contributions.

In the following sections we will review the recent reforms in the EU countries. We then introduce with some detail the Belgian tax reform (2001) and the successive rebate on low skilled SSCs (2004). Finally we compare these measures from the point of view of their budgetary cost.

\subsection{Germany}

As part of the Agenda 2010 - a comprehensive package of measures to re-launch the German economy - in 2001 the German parliament adopted a major reform of the income tax system. In 2003, the Minijob reform significantly extended the social security subsidies on low earnings. The Minijob reform was only a small part of the so called Hartz-IV program which also included extended cuts in unemployment benefits and in income assistance (Wunsch, 2003). In this review, however, we will only focus on the tax and on the Minijob reforms: two measures that have been extensively discussed in the recent German economic literature.

The tax reform raised the basic personal allowance and significantly lowered tax rates. By 2005, year of the full implementation of the tax reform, the tax rate in the first tax bracket fell to $15 \%$ (from $22.9 \%$ in 2000) while the top rate was cut to $42 \%$ (from $51 \%$ in 2000 ). ${ }^{6}$ The effects of a tax and benefit reform may be best summarized by the changes in households' budget constraints. This is done in figures 1 and 2 for a single earner and a two earner household respectively. The budget sets were drawn using the EU-15 Tax benefit model EUROMOD, assuming an hourly wage of 6.6 EUR, which corresponds to 2001 Belgium minimum wage (the French minimum wage for the same year is slightly below this threshold). As it shows in figures 1 and 2, the tax reform had a limited effects on low paid workers. In particular, in the case of single earner households personal income tax plays a marginal role only, while social security contributions are much more important. Reducing the income tax alone does not have an incentive effect in this household typology, at least when working up to 50 hours per week. The incentive effect is slightly stronger in two earners households, given that income taxation is joint in Germany.

In an effort to more efficiently target low skilled workers, several proposals have been made to subsidize social contribution payments. ${ }^{7}$ In 2003 the Parliament finally adopted the Minijob reform. Under the new system earnings up to 400 EUR are exempted from SSCs, and are not liable to the (joint) income tax (the limit was at 325 EUR, before the reform). Once earnings are above this threshold, the part exceeding the threshold is liable to social security payments. Income taxation - however - applies on total income (and not just on the part exceeding the threshold): this explains the drop of disposable income once the 400 EUR threshold is passed. The subsidy, moreover, is not linked to working time and it therefore entails a premium for working shorter hours (especially for medium wage earners). This is partially visible in figure 2: the new exemption from social security contribution shifts the small peak in the budget constraint from more or less 12 to 16 hours per week. The peak comes at lower working hours for persons with slightly higher wage.

\footnotetext{
${ }^{6}$ For more details see Bundesfinanzministerium (2003).

7 The debate mainly concerned the level of the floor on social security contribution, and whether this threshold had to be defined at the household or at the individual level (Bonin, Kempe, and Schneider, 2002).
} 
In figure 1 the effect of the reform is not visible. With one adult working part-time at the minimum wage, the household is still in the benefit range, so every increase in the net income will be offset by a reduction in the social assistance. This points at another result: in presence of very generous social assistance, any effort to modify incentives by decreasing taxation or social security contributions for the low skilled will be offset by the $100 \%$ effective tax rate implicitly built up in most social assistance schemes.

\subsection{The Netherlands}

In 2001, an important tax reform was introduced in The Netherlands. The new tax system explicitly recognizes the difference between more and less mobile productive factors: income from labor, pensions and imputed rents from owner occupied dwellings are globally taxed under one taxing regime. Income from capital on the other hand is imputed from total wealth. ${ }^{8}$

At the same time the reform significantly decreased the tax burden on labor income: new minimum and maximum marginal tax rates are now 33 and 52\% (prior to the 2001 reform the highest marginal tax rate was at $60 \%) .{ }^{9}$ The lower level of taxation is clearly shown in the budget set of two earner households (see figures 2).

A feature that was particularly discouraging to female employment was the existence of a transferable personal tax deduction. If one of the partners did not work (or worked only in a marginal part-time), the credit could be almost fully transferred to the other partner. Given that females are more often the secondary earner in a couple, the measure represented a significant disincentive for women to work more than part-time. ${ }^{10}$

Moreover the former tax allowance on earned income was replaced by a new employment tax credit: the 'arbeidskorting'. The maximum amount of the tax credit is EUR 920, which is reached, with a progressive phase-in, at EUR 15,117, i.e. the full-year equivalent of a full-time at minimum wage. The Dutch tax credit is not phased-out and it is not refundable. Like the German Minijob, he tax credit is not conditional on any working time requirement. This implies that a person working half time at an hourly wage twice the minimum rate, benefits from the same tax reduction as a person working full time at minimum wage. Figure 1 clearly shows the effect of the credit. After the reform, disposable income is highest when working full time. Moreover the tax advantage does not decrease (in absolute value) when working hours increase. It should be noted, however, that for higher than minimum wage earners, the bump in the budget set will be met when working less than full time.

\footnotetext{
${ }^{8}$ Income from wealth is imputed assuming a return rate of $4 \%$, irrespective of the composition of the portfolio. Imputed incomes are then taxed at a flat rate of $30 \%$.

${ }^{9}$ For more details see Ministerie van Financiën (2001).

${ }^{10}$ According to Van Soest and Das (2000), this partially explains the widespread popularity of very short working hours in the Netherlands.
} 


\subsection{Italy}

The reform of the tax system proposed by the Italian government arguably represents the most neo-liberal reform in continental Europe. The reform of the tax system was one of the major pre-electoral engagements of the center-right coalition. However, the business cycle dynamics and the considerable deterioration of public finance in the first years of the mandate have pushed part of the coalition to block the reform. According to the government, however, the tax reform has only been postponed to the next mandate.

Relying on the text of the framework law and the parliamentary text to introduce the bill, Baldini and Bosi (2002) describe the most likely features of the reform and estimate its distributional impact. The plan was inspired by the Flat Rate Tax (FRT) model, yet it was different from the most basic model on several aspects. The existing tax schedules had to collapse into two tax brackets: the marginal tax rate would have been at $23 \%$ between 0 and 100,000 EUR and at 33\% thereafter. ${ }^{11}$

To avoid imposing a heavy tax burden on very small incomes and to partially preserve the progressiveness of the tax system, a series of (non-refundable) tax credits were supposed to come along with the flat tax reform. The tax credit, or No-Tax-Area (NTA) were designed to vary in accordance with personal labor market status (i.e. inactive, employee or self-employed) and family conditions (number of dependents), but there is much uncertainty about their level. ${ }^{12}$

In figures 1 and 2 the NTAs are not simulated, while the flat tax rate is at $23.3 \%$. The figures do not refer to the actually planned tax reform, but to an extremely similar FTR reform analyzed by Aaberge, Colombino, and Strøm (2004).

In the case of a FTR reform low wage earners are worse off, while high wage earners witness a decrease in their tax liability. For low wage earners, the new budget curve lies under the pre-reform budget curve. When working close to 80 hours per week, however, the post reform budget curve cuts the pre reform curve.

\subsection{UK}

In the late 90s, the Working Family Tax Credit (WFTC) replaced the Family Credit (FC) which had been introduced in 1986 as a form of support for low-income working parents. The WFTC which, relative to the FC, substantially increased the amount of the benefit, is conditional on working at least 16 hours per week, and not 24 as was the rule before 1992. In 2003, the WFTC was redesigned: social assistance for children (which is added to the universal child benefit) was made means tested and not conditional on the employment status of parents, whereas the in-

\footnotetext{
${ }^{11}$ According to Baldini and Bosi (2002) taxes in the new system will be flat-rate for about $99 \%$ of taxpayers.

${ }^{12}$ In an early proposal the maximum NTA was supposed to vary from 3,000 EUR for an inactive single to around 11,000 EUR for an employee with dependent partner and one dependent child (3,000 EUR as a basic tax credit plus 4,000 EUR as a tax credit on employment income and 2,000 EUR for each dependent family member). Beyond the NTA, the tax credit would be tapered away at a rate of probably 40-50\%, meaning that no tax credit would be available for a tax payer with taxable income around 35-40,000 EUR (the figure refers to an employee with two dependent family members). The NTA is quite similar to the Dutch arbeidskorting, with the main difference that the former is phased out after attaining a certain maximum value.
} 
work benefit was extended to people without children. The WFTC was therefore split into a Child Tax Credit (CTC) and a Working Tax Credit (WTC), which entails a clearer separation of anti-child-poverty and Making-Work-Pay measures.

The new WTC is available to both singles and couples with or without children, although amounts vary according to family situation. Couples and lone parents are entitled to a maximum refundable credit of $£ 3,025$ per year, plus a bonus of $£ 620$ per year for those working 30 hours or more a week. Moreover, families with children in which all adults work, care or are disabled may receive help to cover costs of approved child care. Families with annual incomes below $£ 5,060$ are entitled to the full amount; at income levels above this threshold a taper of $37 \%$ reduces entitlement.

Figures 1 and 2 show the switch from FC to the WFTC. This is not the most recent reform, but like in the case of Italy, it is of most interest to focus on a reform whose potential labour supply effects have been estimated (Blundell, Duncan, McCrae, and Meghir, 2000).

\subsection{France}

Up to 1998, France found itself in a paradoxical situation: an inactive person collecting the Revenu Minimum d'Insertion (RMI) was receiving more than a worker working half time at minimum wage. $^{13}$

In 2000, the French government reformed the housing allowance and introduced an in-work benefit, the Prime Pour l'Emploi. To be eligible, at least one member of the household must be employed, taxable income (jointly assessed at household level) must be lower than a certain amount (EUR 30,050 for a couple with two children) and individual earnings must be between EUR 3,265 and EUR 23,207 per year. The level of the subsidy was originally $2.2 \%$ of net earnings, which for a minimum wage worker correspond to about 300 EUR per year. The original plan of the Jospin government was to increase the benefit to $4.4 \%$ and to $6.6 \%$ of net earnings in two steps. An interesting feature of the PPE - at least in its original version - is that it is strictly connected to hours worked: earnings are in fact recomputed in full time equivalent, so that only unskilled workers with low hourly earnings are targeted, clearly distinguishing between low skills and low effort. In 2003, the government increased the benefit to $4.4 \%$ of net earnings and introduced a bonus for working part time. A full-time worker may therefore be eligible to a maximum benefit of EUR 443 per year, whereas a part-time worker has the right to a maximum of EUR 322 per year (i.e. slightly more than half the full-time benefit). The French PPE presents some hybrid features: it is means tested on household income, but at the same time it is individualized in the sense that it is also conditional on individual earnings and more than one person in the household may be eligible. Figures 1 and 2 show disposable income before and after introducing the PPE. The effect is smaller than that of the WFTC, but the phasing out is much smoother and, contrary

\footnotetext{
${ }^{13}$ Working full-time at the minimum wage, on the other hand, brought about a financial gain of about EUR 230 per month. Hardly a significant incentive to take up work, especially if we consider the fixed costs a worker incurs when taking up a job. Such an inactivity trap was due to the fact that earned income was taken into account in the income test to compute housing allowance eligibility, whereas the RMI was disregarded (Périvier, 2003).
} 
to the WFTC, the PPE does not recreate flat segments into the budget line. This is due to the fact that eligibility to the PPE depends on hourly wage, so that only the low skilled are actually targeted. The better targeting of the instrument allows for a much more generous phasing out. Moreover the benefit is phased in with working time, so that full time workers are entitled to a higher premium than part time workers.

\section{Reforms in Belgium}

In August 2001 the Belgian Parliament implemented the tax reform announced by the federal government in its Policy Plan of 17th October 2000. The reform was phased in progressively between 2001 and 2005. One interesting feature of the reform is that it included both a generalized tax reduction and the introduction of a refundable earned income tax credit. However, in 2004 the refundable earned income tax credit was replaced by a rebate on low skilled social security contributions. The latter measure, it was argued, would be more effective in promoting the employment of the low-skilled.

The principal axes of the original reform were:

1. the increase in deductions for working expenses (from 20 to $25 \%$ of gross earnings up to 5,329 EUR);

2. the broadening of the central tax brackets (the lowest boundary of the $45 \%$ marginal tax rate bracket was increased, while the upper boundary of the $30 \%$ and $40 \%$ bracket were increased);

3. the abolition of the highest marginal tax rates (from $55 \%$ and $52,5 \%$ to $50 \%$ );

4. the alignment of the tax exempt income quotas for couples to the level of that for singles (from 3,250 EUR to 4,095 EUR);

5. and the introduction of an earned income tax credit - CIBRAP hereafter. ${ }^{14}$

The CIBRAP was introduced with the explicit aim of making employment financially more attractive, especially to youngsters and women, and - at the same time - redistributing income in an effort to reduce the poverty risk of less productive workers (Ministère de Finances, 2002).

The Belgian CIBRAP is quite similar to the Dutch 'arbeidskorting': it is fully individualized and not means-tested on household income, but, similarly to the Anglo-Saxon measures, it is refundable. ${ }^{15}$

\footnotetext{
${ }^{14}$ Crédit d'Impôt pour les Bas Revenus d'Activité Profesionnelle.

${ }^{15}$ Individualization of the benefit implies - for example - that both members of a couple are potentially eligible and more importantly - the income of one partner has no effect on the eligibility of the other. The main drawback of the family based IWBs is therefore avoided. On the other hand, the broad eligibility conditions imply that the amount of the benefit is much lower than the WFTC. Also, differently from the WFTC and the PPE, the CIBRAP is not scaled according to family conditions, so that the number of dependants is not taken into account. Such a feature may cause the benefit to be quite ineffective in tackling inactivity traps, as means-tested benefits like the MINIMEX are scaled on household size. The net replacement rate of inactivity by employment will therefore be higher for single women on social assistance than for single mothers.
} 
Other characteristics of the tax credit closely match the characteristics of the instruments that already exist in other countries: the benefit is phased in and phased out with a relatively low taper, it is conditional on working at least 13 hours and it is administered by the fiscal authorities. The maximum amount of the credit, however, was limited to just above 500 EUR per year. ${ }^{16}$

One year before reaching its full level, the CIBRAP was replaced by the employment bonus, BE hereafter ${ }^{17}$ - a rebate on low wage employees' SSCs. ${ }^{18}$ The term 'Bonus' is somewhat misleading, and has generated some confusion in the public debate. The bonus is a structural reduction on quarterly SSC paid by low wage employees. The first reduction had been introduced in 1999 . In 2001 it consisted of 81.8 EUR per month, for full time equivalent gross employment incomes between 877 and 1,147 EUR. ${ }^{19}$ The benefit was then phased out with a rather sharp taper rate of $36.5 \%$, to be fully exhausted at 1,367 EUR. Following the introduction of the new bonus, the base reduction will reach 140 EUR in 2006. The minimum income threshold has been abolished, while the upper threshold was brought to 1,210 EUR per month. After this level the reduction is phased out with a taper of $17.8 \%$, to be fully exhausted at an equivalent monthly full time gross income of 2,000 EUR. In principle, a minimum wage legislation applies in Belgium. In 2001 full time minimum wage was 1,140 EUR per month. This implies that the bonus should never exceeds SSC due. In some minor cases (mostly for young apprentices) the minimum wage legislation does not apply. In this case the bonus may even become refundable.

The appealing feature of the bonus is its link with equivalent full time earnings: gross earnings are first transformed in full time equivalent, then the maximum reduction to which a worker might be entitled is scaled to the amount of hours worked. This way, employees working full time are entitled to the full reduction, while part time employees will only have half of the maximum reduction. This feature is indeed an improvement with respect to the previous CIBRAP given that the latter did not distinguish between low productivity and low effort. Moreover, low wage workers benefit from the SSCs deductions immediately (instead of having to anticipate the following year's tax reimbursement). ${ }^{20}$

Figures 1 and 2 show disposable income before the originally planned reform and the current reform (hereafter respectively reform I and reform II). Several aspects are particularly interesting: in the case of single earner households neither reform modifies the incentives to take up work up to 34 hours per week. The increase in disposable income is highest when working full time.

\footnotetext{
${ }^{16}$ Eligibility starts when net earned income (i.e. gross earned income net of SSCs and imputed professional expenses) is above EUR 3,750. Between this lower threshold and EUR 5,000 the benefit will be phased in very sharply at a rate of $40.5 \%$ (i.e. the benefit increases by EUR 40.5 for every EUR 100 earned between EUR 3,750 and EUR 5,000). Between EUR 5,000 and EUR 12,530 EUR the benefit amounts to EUR 506 and between EUR 12,530 and EUR 16,280 the benefit is phased out at a rate of $13.5 \%$, meaning that EUR 13.5 of benefit are lost for every additional EUR 100 earned.

17 Bonus à l'emploi.

${ }^{18}$ Other minor measures (accounting for less than $15 \%$ of the total budget) were also included in the reform, but they will not be examined in the present study since they are not likely to affect labor supply. For details on the other measures, see Ministère de Finances (2002), and an evaluation by Vallenduc (2002).

19 This figures refer to white collar workers. For blue collars workers the maximum amount and the income limits are slightly higher due to differences in the social security regime.

20 The CIBRAP did not disappear completely: it is still in place for self-employed, given that the latter do not benefit from the reductions in social security contributions.
} 
At minimum wage, moreover, both reforms have a similar effect on disposable income. At higher hourly wages, however, the bump in the budget line corresponding to the CIBRAP, is reached when working less than full time. The same does not apply under reform II: the reduction increases with working time and it is always at its highest level when working full time. In the case of double earner households this effect is even clearer: when working less than full time reform I is more advantageous than reform II, but the reverse applies when working more than full time. Again, for hourly wages above the minimum level the cutting point between the two budget lines lies before the 40 hours/week point. Therefore, while both reforms might have a similar impact on incentives to take up work, the BE does not entail the negative effect on working hours which is clearly present in the CIBRAP (at least for workers earning more than the minimum wage).

\section{Tax-benefit reforms and labor supply: methodological framework}

The fiscal reforms that have been implemented in the US and EU countries in the last decades have fostered a growing literature on the impact of changes in the budget constraints on labor supply.

A variety of methodological approaches have been used for in-depth analysis of the labor supply impact of tax reforms. Such studies have been of crucial importance to evaluate policy measures in terms of costs and benefits and potential distortions on the behavior of different social groups. Some of these approaches are ex-post and are based on natural experiments or the methodology of differences in differences (Blundell, Brewer, and Shephard, 2005). Given the time delay in the availability of data such analyses are mostly of historical interest.

Ex-ante evaluations however are also possible. The latter rely on a sufficiently large sample of the targeted population, on a detailed microsimulation model and on an econometrically tractable choice model.

\subsection{Data and microsimulation model}

This study relies on the most recent wave of the PSBH, i.e. the 11th wave collected in 2001 and containing information on the incomes of year 2000. Unfortunately this was the last wave of the survey, so that it will not be possible to assess the reform ex-post using techniques based on microdata (e.g. difference in differences). Descriptive statistics of the adult population are presented in table 1. We focus on the subpopulation of households where both spouses are in working age and available for the labor market (i.e. not in full time education, not disabled, not retired and not self-employed). ${ }^{21}$

Modété - the Belgian module of EUROMOD - reproduces for each household the set of net disposable income corresponding to different combinations of working hours of the male and female

\footnotetext{
${ }^{21}$ Of course self-employed have also a flexible labor supply. However, the information on hours worked and on gross earnings are often reported with a high degree of approximation (when not missing). The estimates of a labor supply model for the self employed are therefore highly unreliable.
} 
partner.

For workers with observed wages, gross income across different labor supply alternatives are computed assuming a constant hourly wage rate. For inactive and unemployed workers hourly wages were imputed separately for males and females using regression techniques. For females the censoring effect was more significant: we therefore used a Heckman correction model. In the case of males the hypothesis of null correlation between the residuals of the labor supply and the wage equation could not be rejected, so we used a standard regression model estimated on the sample of employees.

Estimates of the wage equations are presented in table 2. Coefficients all have the expected sign, and the inverse Mill's ratio (lambda) hints at a significant selection bias for females. In particular the constant for female wage is somewhat lower than that of males, while the effects of schooling and potential experience have a similar order of magnitude. The prediction error is given by the RSME, and - as expected - is slightly larger for females than for males. The error are nevertheless in the order of magnitude of other recent studies (Laroque and Salanie, 2002).

Once household gross incomes corresponding to the different working time alternatives have been computed, the microsimulation model computes the corresponding set of disposable incomes. These are reported in the table 3 , which also reports other demographic statistics for the subsample used in the estimation procedure.

\subsection{Behavioral model and econometric framework}

Traditional approaches, based on the estimation of continuous labor supply functions, have proven computationally cumbersome even in the simplest case, let alone in the more complex cases in which multiple welfare programme participation, the social stigma of benefit take up and the fixed cost of labor supply are considered. Recently, however, the analysis has been greatly simplified by the discrete approach proposed by van Soest (1995). Such models explicitly recognize the institutional constraints on labor supply which result in a limited set of working time alternatives (inactivity, several part-time categories, full-time and over-time). ${ }^{22}$

Most importantly, however, the computational burden of estimating labor supply functions boils down to ML estimation of a more or less articulated conditional logit function.

Once preference parameters are estimated, optimal behavior conditional to the post reform budget constraints is used to predict post reform participation and working time decisions. ${ }^{23}$

Discrete choice models of labor supply are based on the assumption that a household can choose among a finite number $J+1$ of working hours ( $J$ positive hours and non-participation); each hour $\mathrm{j}=0, \ldots, \mathrm{J}$ corresponds to a given level of disposable income $C_{i j}$ (we suppose here that choice $\mathrm{j}=0$ corresponds to non-participation) and each discrete bundle of leisure and income provides a different level of utility. The approach has become standard practice as it provides a straightforward way

\footnotetext{
${ }^{22}$ Although this is mostly the case, the methodology can be applied to a larger number of budget points (Van Soest, Das, and Gong, 2002)

${ }^{23}$ See van Soest (1995), Keane and Moffit (1998), Hoynes (1996), Blundell, Duncan, McCrae, and Meghir (2000), Van Soest and Das (2000), Bonin, Kempe, and Schneider (2002), Bargain (2004a) and Haan and Steiner (2004).
} 
to account for taxes and benefits, hence nonlinear and nonconvex budget sets, and the joint labor supply of spouses. In effect, choices $\mathrm{j}=0, \ldots, \mathrm{J}$ in a couple correspond simply to all the combinations of the spouses' discrete hours. We assume that females may choose between working $0,20,40$ or 50 hours, while men may work 0,40 or 50 hours, ${ }^{24}$ the database contained almost no case of males in couples working part-time. The interaction of the two choices generates 12 alternative characterized by triplets of disposable income, leisure of the female spouse and leisure of the male spouse. It should be noted here that the term leisure should be interpreted as non labor market time. Household's utility $V_{i j}$ derived by household $i$ from making choice $j$, corresponds to the sum of the deterministic part of the utility $U_{i j}$, which is assumed to depend on a function of spouses' leisures $L f_{i j}, L m_{i j}$, disposable income $C_{i j}$ (equivalent to aggregate household consumption in a static framework) and household characteristics $Z_{i}$, and of an unobserved random term $\epsilon_{i j}$ :

$$
V_{i j}=U\left(H f_{i j}, H m_{i j}, C_{i j}, Z_{i}\right)+\epsilon_{i j}
$$

When the error term $\epsilon_{i j}$ is assumed to be identically and independently distributed across alternatives and households according to a $E V-I$ distribution, McFadden (1973) proves that the probability that alternative $k$ is chosen by household $i$ is given by:

$$
P_{i k}=\operatorname{Pr}\left(V_{i k} \geq V_{i j}, \forall j=0, \ldots, J\right)=\frac{\exp U\left(H f_{i k}, H f_{i k}, C_{i k}, Z_{i}\right)}{\sum_{j=0}^{J} \exp U\left(L f_{i j}, L f_{i j}, C_{i j}, Z_{i}\right)}
$$

The likelihood for a sample of observed choices can be derived from that expression and maximized to estimate the parameters of function $U$. When actual working hours are used, the econometrician assumes that individuals choose freely their working hours and face no demand-side constraints.

In the following, we assume a quadratic specification of the utility function as in Blundell, Duncan, McCrae, and Meghir (2000). Hence, the utility function of a couples household has the following form:

$$
\begin{aligned}
U_{i j}=\alpha_{c} C_{i j}+ & \alpha_{c c} C_{i j}^{2}+\alpha_{h f} H f_{i j}+\alpha_{h h f} H f_{i j}^{2}+\alpha_{h m} H m_{i j}+\alpha_{h h m} H m_{i j}^{2} \\
& +\alpha_{c h f} C_{i j} H f_{i j}+\alpha_{c h m} C_{i j} H m_{i j}+\alpha_{h m h f} H f_{i j} H m_{i j}-\beta_{p t} .
\end{aligned}
$$

We assume that preferences vary across households through taste-shifter (age, number of small children):

\footnotetext{
${ }^{24}$ Hours worked were censored at 80 hours per week and discretized according to the following rule:
}

$$
\begin{array}{r}
H=0, \forall h \in[0,10] \\
H=20, \forall h \in[11,34] \\
H=40, \forall h \in[35,44] \\
H=50, \forall h \in[45,80]
\end{array}
$$




$$
\begin{array}{r}
\alpha_{c}=\alpha_{c 0}+\alpha_{c 1} X_{1} \\
\alpha_{h f}=\alpha_{l f 0}+\alpha_{l f 1} X_{2} \\
\alpha_{h m}=\alpha_{l m 0}+\alpha_{l m 1} X_{3} .
\end{array}
$$

We follow van Soest (1995) and introduce a dummy variable for the part time $\beta_{p t}$. The dummy variables may capture different aspects not explicitly treated in the model: search costs, rationing effect and dynamic maximization.

Parameter estimates for the behavioral model are shown in table 4. The results are in line with theoretical predictions and recent empirical findings. The coefficients imply marginally decreasing utility of consumption and leisure. Together with the interaction terms, these coefficients determine the elasticity of labor supply. The preference for leisure displays a clear pattern with respect to age and number of small children. Observed heterogeneity on the other hand does not seem to explain the preference for income. The derivatives with respect to leisure show that for a significant share of the population positive monotonicity in leisure is not respected. As stressed by Euwals and van Soest (1999), there is no necessity to restrict preferences relative to the taste for leisure. With respect to income, however, preferences are well behaved, and no restriction had to be imposed in the estimation.

The quality of the model's predicting power may be best judged by comparing the observed and predicted frequencies for each alternative. The predicted frequencies, reported in table 5 are obtained by averaging up, over the whole sample, each household's probability of choosing a given regime.

In the present non-linear model, labor supply elasticities cannot be derived analytically but it is still possible to simulate numerically the impact of a marginal increase in gross hourly wages on hours of work and participation. Instead of the 'aggregated frequencies' technique, we follow the calibration method which is consistent with the probabilistic nature of the model at the individual level. ${ }^{25}$ The elasticities presented in table 6 are mean elasticities.

There are no recent studies on labor supply elasticity for Belgium using a similar methodology. Elasticities appear to be very small and are mostly driven by changes in the participation rate rather than by changes at the intensive margin.

This finding is in line with the experience of other Continental European countries. Table 7 shows recent labor supply elasticity estimates derived using a similar methodological framework. ${ }^{26}$ Male labor supply elasticities for Germany tend to be comparable to those of Belgium (just around

\footnotetext{
${ }^{25}$ It simply consists in drawing the random terms of the model from their distributions until a match between predicted and observed choice is observed for each household. These draws are then used for predicting labor supply responses to a shock on wages or a tax reform. Following the reform, in fact, the structural part of the utility varies, while the drawn errors are held constant. Averaging over a large number of draws provide robust transition matrices (Creedy and Kalb, 2005).

${ }^{26}$ The study of Aaberge, Colombino, and Strøm (2004) is the only one which adopts a slightly different methodology. The labor supply model is still discrete choice. Rather than assuming a constant wage rate, the authors estimate a joint distribution of wage and working time. Each individual is then characterized by a distribution of probability of finding a given job characterized by a couple wage-working time. The model is estimated by selecting out several point in the time hours distribution.
} 
.20), while female labor supply elasticities compare well with the French estimate. Male labor supply elasticities in the Netherlands and in Italy are significantly lower (from .08 to .10 and .12 respectively). On the other hand female labor supply appears to be more elastic in both countries (from .52 to .71 and .66 for the Netherlands and Italy respectively). ${ }^{27}$ Note, however, that these differences are not always statistically significant. In the case of Belgium, at least, the confidence intervals for male and female elasticities partially overlap. ${ }^{28}$

\section{Evaluations of reforms in the other EU countries}

Table 8 summarizes the estimated impact of the reforms surveyed in section 2 . These evaluations are all based on the methodology described in the previous section. ${ }^{29}$

Haan and Steiner (2004) evaluate the effects of the Agenda 2010 tax reform in Germany. The latter estimate that the reduction of the tax burden on labor is likely to increase total labor supply by around $1.2 \%$ for females and $.9 \%$ for males. This reform did not target the very low skilled population. For those with hourly wages in the range of 6-7 EUR, the budget constraint is hardly modified. At higher wage rates the incentive system is modified only when working full time. This is linked to the fact that for low skilled workers social security contributions tend to be much more important, while the relative weight of income taxation tend to be marginal.

Steiner and Wrohlich (2005) assess the impact of the Minijob reform. They find moderate participation effects. Female in couples increase working hours, but this gain is partially offset by a reduction in male hours supplied. The result is hardly surprising: the reform increases the discontinuity in the budget line. In our example (see figure 2), after working around 15 hours at an hourly wage of 6.6 EUR, household disposable income decreases due to the setting in of joint taxation. The same level of income is then reached again when working about 20 hours. This creates an unambiguous incentive to reduce labor supply to the level of the peak. While some new workers may be pushed to participate in the labor market, some low skilled already in employment will be pushed to reduce labor supply. Considering the labor supply of singles, the total effect on hours worked is negative.

For the Netherlands, Van Soest and Das (2000) apply the discrete hours setting to estimate the labor market impact of the tax reform similar to the one actually adopted by parliament and described above. They conclude that the tax reform will have a significant impact on female labor supply: average working hours will increase by over 4\%. Part of the increase is driven by a change in the participation rate (1.48\%). The introduction of the 'arbeidskorting' clearly represents an incentive to take up work. However a substantial increase in working hours also comes from females in employment working in marginal part time position. Indeed prior to the

\footnotetext{
${ }^{27}$ Unfortunately there is no study based on discrete hours modeling which explicitly reports the size of labor supply elasticities in the UK.

${ }^{28}$ The intervals were computed by bootstrapping 100 times from the asymptotic distribution of the parameters estimates and re-calibrating.

${ }^{29}$ Aaberge, Colombino, and Strøm (2004) use a partially different methodology (see note 26) and Bargain (2004a) models only the labor supply of females in couples, assuming a male chauvinist labor supply model, where males have a fixed labor supply.
} 
reform, secondary earners could transfer part of the tax credit to the primary earners, so that several households found it convenient that secondary earners would supply hours until the point where a further increase in working time would reduce the transferable part of the tax credit. Van Soest and Das (2000) however, do not decompose the effect of the reform, so that it is not possible to identify the contribution of each measure.

In the case of Italy, the impact of a revenue-neutral FRT tax reform on labor supply was estimated by Aaberge, Colombino, and Strøm (2004), almost 4 years before such a proposal begun to be discussed. The revenue neutral reform analyzed in the paper implied an equivalent tax rate of $23.3 \%$ - based on the 1992 tax benefit legislation. The microsimulation results suggest that participation is likely to decrease (-1.8 percentage points for females), but the total amount of hours is likely to increase $(+5.8 \%$ and $+1.17 \%$ for females and males respectively). The latter result is due to the fact that average tax rates for households with lowest earning capacity increase pushing their members out of the labor market. For most other households, however, there is an incentive to supply more hours of work, given the decrease of the marginal tax rate.

Blundell, Duncan, McCrae, and Meghir (2000) develop a full structural model of discrete-hours labor supply and estimate the impact of the transition from the FC to the WFTC both on couples and on single females. They find evidence of an increase in labor market participation of lone parents $(+2.2$ percentage points) and to a lesser extent of men, although it is partially offset by a reduction in the hours supplied by men already in the labor market. The labor supply reduction of female secondary earners is however significant (hours worked decrease by $+0.18 \%$ ). This is hardly surprising given the important flattening of the budget line. Indeed in single earner households, the hours requirement and the premium clearly increase incentives to move into employment, but the household level targeting implies that households with secondary earners (i.e. females in couples) suffer much less from a reduction of hours worked. The small financial loss could then be more than outweighed by an increase in non market time. The predicted net effect of the WFTC is therefore modest, and the high costs of the measure are mainly justified in view of its redistribution effects. ${ }^{30}$

Bargain (2004a) evaluates the impact of the 2003 French PPE and alternative benefits on the employment incentives of women living in de facto couples and predict relatively small employment effects $(+0.4 \%)$. The reform is indeed marginal, but it has significant effects: most importantly the increase in participation does not bring about a decrease in hours worked by the population already in employment (although a negligible number of females - about 4,000 - may be pushed towards inactivity given that the spouse now has higher net earnings). The limited counter effects in the PPE reform are due to the double targeting of the instrument: while the household income requirement is fairly large, the wage requirement targets workers with wages around the minimum wage. Moreover the scaling of the benefit according to working time, increases the benefit for employees working full time. The 2003 reform partially goes in the wrong direction, as it introduces a part time premium that was intentionally avoided in the first reform, however the size of the premium is evidently not high enough to drive a reduction in working hours as in the case of the

\footnotetext{
${ }^{30}$ Contrary to other studies, the results for the WFTC are presented in table 8 both for couples and for singles women in order to emphasize the different incentive effects of a measure targeting households.
} 
Minijob and the WFTC.

The increase in hours worked is highest in Italy, although the impact on participation is negative. The second greatest effect in terms of hours comes from the Dutch reform. This is not surprising as the Dutch labor market is characterized by significant dispersion in work hours and one of the main characteristics of the reform is to increase incentives to work full-time for secondary earners (Van Soest and Das, 2000). The largest increase in employment is brought about by the British WFTC, but only for the sub population of lone mothers. This is indeed a particularly vulnerable subpopulation in the UK, but less so in continental countries. Overall, however, the negative employment effect of mothers in couples tend to reduce the positive employment effect.

In the case of Belgium, few studies have addressed the potential effects of the recent reforms. Vallenduc (2002) analyzes the 2001 tax reform in purely static terms and focuses on the change in marginal and effective tax rates as well as changes in replacement rates, concluding that the reform is likely to have a positive impact on labor supply (although the increase in replacement rates is not concentrated where poverty traps are most significant). Saintrain (2002), on the other hand, uses a macro model to estimate the impact of the 2001 tax reduction. The model he uses is almost totally demand-driven (although the author concedes that the tax reform could bring about a slight increase in labor supply, and thus a decrease in the NAIRU. ${ }^{31}$ The author argues that the reform could bring about a partial decrease in the wage wedge, thus increasing the demand for labor. ${ }^{32}$ According to estimates using the macro model of the Federal Planning Bureau (HERMES), potential additional employment could be at around 25,000 units.

Vermeulen (2006) analyzes the impact of the 2001 tax reform. His study, although micro-based, adopts a totally different framework: household members are not assumed to behave a single utility maximizing agent, but rather as a couples of individuals interacting in a collective setting. The author predicts that the reform will have only a marginal effect, but he limits the analysis on the very small sample of households without children. Following Bargain (2004a), Orsini (2005) estimates a model for females in couples only, assuming a fixed labor supply of the male spouses. According to this study, the labor supply of females could increase by over 20,000 units after the tax reform.

We are not aware of any micro-based assessment of potential labor supply effects of the most recent reform.

\section{Evaluation of the reforms in Belgium}

Table 9 shows the predicted effect of the reforms carried out in Belgium on the labor supply of couples. Net increases labor supply is expressed both in terms of additional individuals entering the labor market and in terms of additional full time equivalent positions. Following reform I, labor supply is estimated to increase by around 26,000 FTE units (11,000 additional females and

\footnotetext{
${ }^{31}$ Non-accelerating inflation rate of unemployment.

32 Note that this approach is totally different from our framework. After estimating a labor supply model (infra), we estimate the impact of the fiscal shock, assuming that all the decrease in income tax will correspond to an increase in the net wage that leaves the gross wage unaffected
} 
15,000 additional males). The predicted response is much lower than the estimates of Orsini (2005), probably due to the fact that the current framework allows for a simultaneous behavioral adjustments of both partners.

When looking at the disaggregated effects, the CIBRAP has indeed a positive participation effect, but the latter is partially outweighed by the negative impact on hours of those males and especially females who are already in employment. For at least some of them, the CIBRAP entails an incentive to shorten working times. Indeed while almost 3,000 females would be encouraged to take up a job, almost 1,500 FTE positions are destroyed by the reduction in working time of females already in employment. The scenario is similar in the case of males, where the additional 2,000 new entrants are partially offset by a reduction of 1,000 FTE units.

In the second version of the reform, this does not happen. The reduction in working time of those already in employment is zero for females, and only slightly higher for males. ${ }^{33}$ The incentive to take up work, on the other hand, is much stronger: almost 7,000 units are likely to take up work following the reform of the EB. The difference is especially strong for males. This is not surprising: for workers with a productivity level above the minimum wage the CIBRAP is only interesting when working part-time. With the EB, however, disposable income also increases when working part-time.

The other instruments have a similar impact in both reforms. The broadening of the central tax bracket and the alignment of the tax exempt income quota on the level of single households both have a considerable impact. The latter is especially strong in the case of males $(+6,000 \mathrm{FTE}$ units).

The abolition of the highest marginal tax rate, on the other hand, has the smallest participation effect. The latter was indeed expected as those who are most likely to benefit from this reform are indeed likely to already be economically active. What is quite striking, however, is the negative effect on hours worked of those who are already in employment. Indeed labor supply elasticities tend to decrease as income increases, and for some households in higher income deciles the income effects outweighs the substitution effect, giving rise to negative labor supply elasticities.

Considering all the interactions between the different instruments, the combination of the EB and the tax reform (net of the CIBRAP for employees) has a stronger incentive effect than the reform of the personal income tax alone. In the second scenario the labor supply effect is about 11,000 units FTE higher than in the first scenario (more or less equally split between males and females).

In relative terms the employment rate of females and males is increased by +.76 and +.95 percentage points following reform II, while the increase in hours worked is in the order of $+1.44 \%$ and $+1.20 \%$ for females and males respectively (between a third and a half of the increase is due to the BE alone). Note that in the case of reform I the increase in employment rate would have been in the order of +.7 percentage points for both males and females, whereas the increase in hours worked would have been in the order of $+0.87 \%$.

\footnotetext{
${ }^{33}$ Note there is a higher share of males working over time and that the BE is computed in terms of equivalent full time income, so that the BE does not entail an incentive to work over time.
} 


\section{Conclusion}

This paper reviews tax and benefit reforms recently implemented in several EU countries from the point of view of their impact on labor supply, both at the intensive and the extensive margins.

Most recent ex-ante evaluation literature is based on microsimulation and discrete modeling of labor supply. In the paper we develop a similar model for Belgium. This allows us to estimate the effects of two recent Belgian reforms in a way that is consistent with most of recent ex-ante evaluation literature. Yet a cross country comparison of the effects of the reforms is a potentially dangerous exercise, given that the reforms have different costs. Table 10 compares the cost of the reforms considered. All estimates are based on static microsimulation. Such simulations, also known as 'day-after' simulations, do not take into account feedback effect from changes in agents' behavior.

The aggregate cost of the Belgian reforms is slightly lower than the German and Dutch reforms (1.25\% against $1.65 \%$ and $1.55 \%$ of GDP, respectively). Lower and upper bound estimates in the case of Italy depend on the extension of the NTA. In the lower boundary case (where the NTA is set to zero), the reform is comparable in terms of budgetary efforts, to those of the Netherlands and Germany. The presence of the NTA, however, considerably expands the cost of the reform.

When it comes to MWP instruments, the British WFTC clearly stands out as the most expensive measure (.54\% of GDP). Note that this figure does not correspond to the cost of the WFTC, but to the cost of the switch from the FC to the WFTC. The total budgetary cost of the reform is therefore much larger. On the other extreme, the German Minijob may be definitely characterized as a marginal measure: it was predicted to absorb only about .05\% of the GDP. Indeed, as shown in the budget lines, the reform only targets workers in very marginal part time. The French PPE is also relatively marginal (.14\% of GDP). Its budgetary cost is almost a quarter of that of the WFTC. The Belgian CIBRAP costs slightly more than the PPE (.17\% of GDP), whereas the EB is slightly more expensive (.22\% of GDP). Note however that reform I and reform II are broadly comparable in terms of budgetary cost: lower social security contributions in fact are compensated by an increase in gross taxable income.

Although not available in all cases surveyed, the budgetary cost per job created (or rather per job taken up) is an interesting statistics to look at. In terms of FTE position taken up, the estimated budgetary cost is in the the order of 200,000 EUR for the WFTC, 170,000 EUR for the German tax reform and 120,000 EUR for the French PPE. In the case of Belgium the cost for job taken up varied from 150,000 EUR in reform I to 100,000 EUR in reform II. Clearly, the low labor supply elasticities, imply enormous cost per job taken up. ${ }^{34}$

It should however be stressed that the above figures should be interpreted cautiously given the difference in sampling and weighting procedures as well as in initial conditions - i.e. employment

\footnotetext{
${ }^{34}$ These figures may be easily compared with other studies. The IFS estimates that the WFTC has an average cost per job created in the order of 300,000 EUR. Bargain and Orsini (2006) simulate the introduction of a low wage subsidy similar to the French PPE (but without any household related supplements) for France, Germany and Finland. The estimated cost for job taken up varies from 65,000 EUR (France) to 166,000 EUR (Finland). These figures would be even higher if the cost would be expressed in terms of FTE positions.
} 
rates, distribution of working time and structure of preferences. Moreover a classification of the reforms on the basis of the sole criterion of their potential impact on the labor supply would be unfair. Equity considerations might indeed reverse the judgements on the relative efficiency of the different measures.

It seems therefore more appropriate to draw some very general conclusions from the multiple experiences taken in consideration and, possibly, to derive some policy guidelines for future tax and benefit reform.

As shown in the German case, focusing on personal income tax alone might not be very effective in increasing labor supply amongst the low skilled population. While income tax might be particularly low for workers with weak earning capacity, SSCs are mostly not progressive, and tend to significantly reduce decrease the financial gains to take up work in the low skilled population. The Minijob reform was partially an attempt to target the low skilled population by reducing the social security contributions on the low earnings.

Similarly, the WFTC scheme increases the disposable income of poor working households. The scheme, however, is based on a household level means-test. Secondary earners therefore tend to reduce labor supply in order to enter the eligibility range. In the case of singles, this effect is not encountered, given that eligibility is conditional on working at least 16 hours and that there is a premium for working more than 30 hours.

In the case of Germany, the eligibility to the SSCs subsidy is assessed at personal level, but there is no working time requirement. This imply that medium and highly skilled workers could reduce their working time to marginal working part time in order to benefit from the subsidy. In the case of males the reform is therefore predicted to have a negative impact on working hours. An hours requirement, like in the case of the WFTC, would have partially reduced the negative impact of the reform on working hours.

This point is particularly evident in comparing the two subsidies introduced in Belgium in 2001 and in 2004. The positive employment effect of the CIBRAP, is indeed strongly reduced by the negative effect of the population already at work. However the BE avoids this negative outcome by tying the size of the subsidy to equivalent full time earnings and to hours worked. The same structure was partially present in the French PPE, but was partially modified by subsequent policy change.

That joint assessment of household income (both for tax and subsidy purposes) might have potentially perverse effects is also evident from the Dutch experience. Until before the reform spouses were allowed to transfer personal earnings tax allowances above a determined minimum level. This pushed several secondary earners -mostly women- to work very marginal part time, in order to maximize the transferable part of the personal allowance. ${ }^{35}$ Indeed one peculiar aspect of the evaluation of the Dutch reform is the increase in the working hours of females, which is only partially driven by a change in participation.

\footnotetext{
${ }^{35}$ Steiner and Wrohlich (2004) provide further evidence of the negative effects of joint income taxation on the labor supply of females. The authors - who use again the discrete choice setting - show that the individualization of the tax system might have substantial incentive effects on the labor supply of secondary earners.
} 
The reduction of highest marginal tax rates, on the other hand, tend to have a negligible impact on labor supply. This is witnessed by both the Dutch, the Italian and the Belgian evaluations. In the case of the Netherlands the increase in hours worked (for males) is particularly small. The same applies to the flat tax rate reform in Italy: participation is unchanged while there is only a small increase in working hours. In the case of females the flat tax rate pushes some workers out of the labor market, while average working hours on average increase. The latter depends on the distribution of labor supply elasticity in the working population. Indeed while low income households tend to be extremely reactive in changes to the tax system, higher income household tend to be on average less reactive, due to the interaction between substitution and income effect. This is particularly clear by looking at Belgium, where the increase in hours worked coming from new entrants is almost totally outweighed by a reduction in the working effort of the population in employment.

To sum up, the above survey points at the following evidence:

1. generalized tax cuts may not be the most effective way to stimulate labor supply; in particular cutting the highest marginal rates has ambiguous effects on the supply on hours worked;

2. given the progressivity of most tax systems, rebates on SSCs tend to be more effective than tax cuts in promoting the labor market participation of the low skilled population;

3. joint assessment of income for both purposes of taxation and benefit eligibility has unambiguous negative effects on the labor supply of secondary earners (i.e. mostly women);

4. MWP policies can be very effective in promoting the labor supply of the low skilled;

5. the design of MWP policies is of crucial importance: only instruments that correctly distinguish between low effort and low productivity may successfully counter the potential negative impact on the hours worked of the population already in employment. 
Tab. 1: Descriptive statistics, population in working age ${ }^{1}$

\begin{tabular}{|c|c|c|c|c|}
\hline \multirow{2}{*}{ Demographical variables } & \multicolumn{2}{|c|}{ Females } & \multicolumn{2}{|c|}{ Males } \\
\hline & & & & \\
\hline Age & 40.901 & 12.497 & 40.799 & 12.557 \\
\hline Married & 0.696 & 0.460 & 0.695 & 0.461 \\
\hline Children $<3$ & 0.082 & 0.274 & 0.078 & 0.269 \\
\hline Children $>3$ and $<6$ & 0.111 & 0.314 & 0.103 & 0.305 \\
\hline \multicolumn{5}{|l|}{ Educational variables } \\
\hline Primary education & 0.181 & 0.385 & 0.216 & 0.412 \\
\hline Secondary education & 0.361 & 0.480 & 0.346 & 0.476 \\
\hline Tertiary education & 0.262 & 0.440 & 0.230 & 0.421 \\
\hline Master or Ph.D. & 0.100 & 0.300 & 0.115 & 0.319 \\
\hline \multicolumn{5}{|l|}{ Labour market status } \\
\hline Retired & 0.063 & 0.242 & 0.063 & 0.244 \\
\hline Disabled & 0.037 & 0.190 & 0.035 & 0.183 \\
\hline On maternity leave & 0.014 & 0.116 & - & - \\
\hline Student & 0.084 & 0.277 & 0.087 & 0.282 \\
\hline Self employed & 0.039 & 0.194 & 0.064 & 0.244 \\
\hline Employee & 0.539 & 0.499 & 0.648 & 0.478 \\
\hline Unemployed & 0.081 & 0.272 & 0.051 & 0.220 \\
\hline Inactive & 0.185 & 0.389 & 0.084 & 0.277 \\
\hline \multicolumn{5}{|l|}{ Hours worked and wages } \\
\hline Hours worked & 17.243 & 18.020 & 26.164 & 20.926 \\
\hline Conditional hours worked & 232.871 & 10.263 & 41.237 & 8.279 \\
\hline Hourly wage $^{2}$ & 6.239 & 0.182 & 6.374 & 0.234 \\
\hline Predicted hourly wage ${ }^{3}$ & 6.170 & 0.196 & 6.261 & 0.299 \\
\hline Observations (unweighted) & \multicolumn{2}{|c|}{2,271} & \multicolumn{2}{|c|}{2,194} \\
\hline Observations (weighted) & \multicolumn{2}{|c|}{$3,466,225$} & \multicolumn{2}{|c|}{$3,025,657$} \\
\hline
\end{tabular}


Tab. 2: Wage equation for females (with Heckman correction) and males $^{1}$

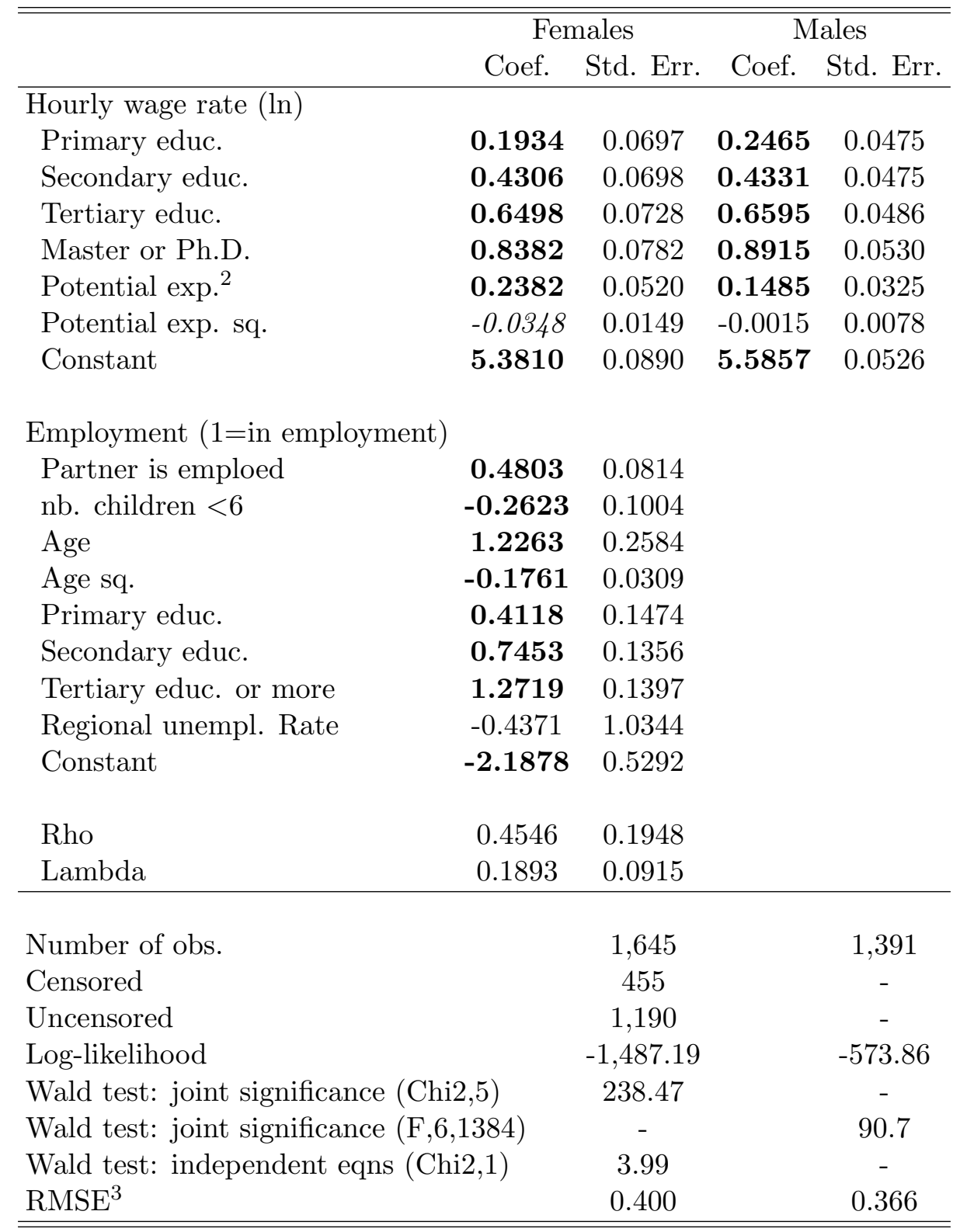

Bold letters indicate significance at the $1 \%$-level, italic letters refer to the $5 \%$-level and underlined letters to the $10 \%$-level.

1 Females and males aged between 18 and 65 either employed, unemployed or inactive.

2 Potential experience is defined as current age net of years of schooling and the age when schooling starts(6).

3 Root of mean squared prediction errors. 
Tab. 3: Descriptive statistics, couples with flexible labor supply $^{1}$

\begin{tabular}{lcc}
\hline \hline & Mean & Std. De \\
\hline & & \\
Demographical variables & & \\
Age female & 40.613 & 9.164 \\
Age female sq. & 17.333 & 7.629 \\
Age male & 42.531 & 9.078 \\
Age male sq. & 18.912 & 7.858 \\
Children $<6$ & 0.381 & 0.685
\end{tabular}

Disposable income by hours worked ${ }^{2}$

\begin{tabular}{|c|c|c|}
\hline$H_{f}=0 ; H_{m}=0$ & 1072.815 & 988.584 \\
\hline$H_{f}=0 ; H_{m}=40$ & 2450.014 & 1487.849 \\
\hline$H_{f}=0 ; H_{m}=50$ & 2803.433 & 1632.742 \\
\hline$H_{f}=20 ; H_{m}=0$ & 1513.229 & 1103.360 \\
\hline$H_{f}=20 ; H_{m}=40$ & 3047.134 & 1578.469 \\
\hline$H_{f}=20 ; H_{m}=50$ & 3389.332 & 1722.605 \\
\hline$H_{f}=40 ; H_{m}=0$ & 2138.294 & 1284.268 \\
\hline$H_{f}=40 ; H_{m}=40$ & 3609.060 & 1718.882 \\
\hline$H_{f}=40 ; H_{m}=50$ & 3943.635 & 1854.593 \\
\hline$H_{f}=50 ; H_{m}=0$ & 2429.082 & 1388.929 \\
\hline$H_{f}=50 ; H_{m}=40$ & 3878.045 & 1806.201 \\
\hline$H_{f}=50 ; H_{m}=50$ & 4211.422 & 1936.650 \\
\hline Number of households (unweighted) & \multicolumn{2}{|c|}{1,152} \\
\hline Number of households (weighted) & \multicolumn{2}{|c|}{$1,951,289$} \\
\hline $\begin{array}{l}{ }^{1} \text { Couples where both members are either e } \\
\text { ployed. }\end{array}$ & nployed, inact & tive or unem- \\
\hline $\begin{array}{l}2 \text { Net household monthly income (EUR). } \\
\text { worked by female and male respectively. }\end{array}$ & and $H_{m} \mathrm{r}$ & efer to hours \\
\hline
\end{tabular}


Tab. 4: Conditional Logit: Preference Structure

\begin{tabular}{|c|c|c|c|}
\hline & & Coef. & Std. Err. \\
\hline$\alpha_{c}$ & $\begin{array}{l}\text { Age female } \\
\text { Age female sq. } \\
\text { Age male } \\
\text { Age male sq. } \\
\text { Constant }\end{array}$ & $\begin{array}{c}-0.1230 \\
0.1380 \\
-0.0113 \\
0.0307 \\
3.2636\end{array}$ & $\begin{array}{l}0.0665 \\
0.0756 \\
0.0702 \\
0.0776 \\
1.4393\end{array}$ \\
\hline$\alpha_{c c}$ & & -0.0199 & 0.0051 \\
\hline$\alpha_{h f}$ & $\begin{array}{l}\text { Age female } \\
\text { Age female sq. } \\
\text { Children }<6 \\
\text { Constant }\end{array}$ & $\begin{array}{c}-0.0036 \\
0.0064 \\
0.0064 \\
\mathbf{0 . 4 3 1 0}\end{array}$ & $\begin{array}{l}0.0021 \\
0.0026 \\
0.0027 \\
0.0547\end{array}$ \\
\hline$\alpha_{h h f}$ & & -0.0033 & 0.0003 \\
\hline$\alpha_{h m}$ & $\begin{array}{l}\text { Age male } \\
\text { Age male sq. } \\
\text { Constant }\end{array}$ & $\begin{array}{c}-0.0068 \\
0.0091 \\
0.3551\end{array}$ & $\begin{array}{l}0.0025 \\
0.0028 \\
0.0564\end{array}$ \\
\hline$\alpha_{h h m}$ & & -0.0023 & 0.0002 \\
\hline$\alpha_{c h f}$ & & -0.0006 & 0.0019 \\
\hline$\alpha_{c h m}$ & & 0.0012 & 0.0014 \\
\hline$\alpha_{h f h m}$ & & 0.0005 & 0.0001 \\
\hline$\beta_{p t}$ & & 1.6801 & 0.1409 \\
\hline $\begin{array}{l}\partial U / \partial \\
\partial U / \partial \\
\partial U / \partial \\
\end{array}$ & & & $\begin{array}{l}0.00 \\
0.53 \\
0.16 \\
\end{array}$ \\
\hline $\begin{array}{l}\text { Numb } \\
\text { Log-li } \\
\text { Wald }\end{array}$ & $\begin{array}{l}\text { bs. } \\
\text { oint significance }(\mathrm{Chi} 2,4)\end{array}$ & & $\begin{array}{c}1151 \\
-2439.42 \\
8.08\end{array}$ \\
\hline
\end{tabular}

Bold letters indicate significance at the 1\%-level, italic letters refer to the $5 \%$-level and underlined letters to the $10 \%$-level. 
Tab. 5: Observed and predicted frequencies

\begin{tabular}{cccc}
\hline \hline \multicolumn{2}{l}{$\begin{array}{l}\text { Weekly working hours } \\
\text { Females }\end{array}$} & $\begin{array}{c}\text { Observed } \\
\text { Males }\end{array}$ & $\begin{array}{c}\text { Predicted } \\
\text { frequencies }\end{array}$ \\
\hline 0 & 0 & 9.9 & 9.01 \\
0 & 40 & 19.55 & 21.44 \\
0 & 50 & 9.9 & 8.91 \\
20 & 0 & 2.35 & 3.50 \\
20 & 40 & 15.38 & 13.93 \\
20 & 50 & 5.99 & 6.29 \\
40 & 0 & 3.13 & 3.31 \\
40 & 40 & 19.64 & 18.69 \\
40 & 50 & 8.43 & 9.18 \\
50 & 0 & 0.96 & 0.51 \\
50 & 40 & 2.95 & 3.45 \\
50 & 50 & 1.82 & 1.77 \\
\hline \hline
\end{tabular}

1 Predicted frequencies are computed by averaging up over the whole sample, each household's probability to chose a given regime.

Tab. 6: Labor supply elasticities

\begin{tabular}{ccccc}
\hline \hline & \multicolumn{2}{c}{ Females } & \multicolumn{2}{c}{ Males } \\
\hline & Hours & Part. & Hours & Part. \\
\hline Own wage elasticity & $\mathbf{0 . 1 9 6 7}$ & $\mathbf{0 . 1 2 7 1}$ & $\mathbf{0 . 1 7 5 3}$ & $\mathbf{0 . 1 6 3}$ \\
& $(.1799, .2688)$ & $(.1208, .1829)$ & $(.1535, .1979)$ & $(.1456, .1896)$ \\
Cross wage elasticity & $\mathbf{- 0 . 0 3 2 7}$ & -0.0239 & 0.0162 & $\mathbf{0 . 0 1 5 9}$ \\
& $(-.07377,-.0571)$ & $(-0.0459,0.0381)$ & $(-.0011, .0028)$ & $(.0019, .0066)$ \\
\hline \hline
\end{tabular}

Elasticities have been computed numerically by increasing by $1 \%$ the gross wage of males and females and recomputing optimal labour supply. Labour supply responses are averaged up over the whole sample. The figures in brackets give the bootstrapped $95 \%$ confidence interval obtained by drawing 100 independent draws of the parameters from the estimated asymptotic distribution of their estimator, calibrating and computing elasticities for each draw. Figures in bold are significantly different from 0 . 


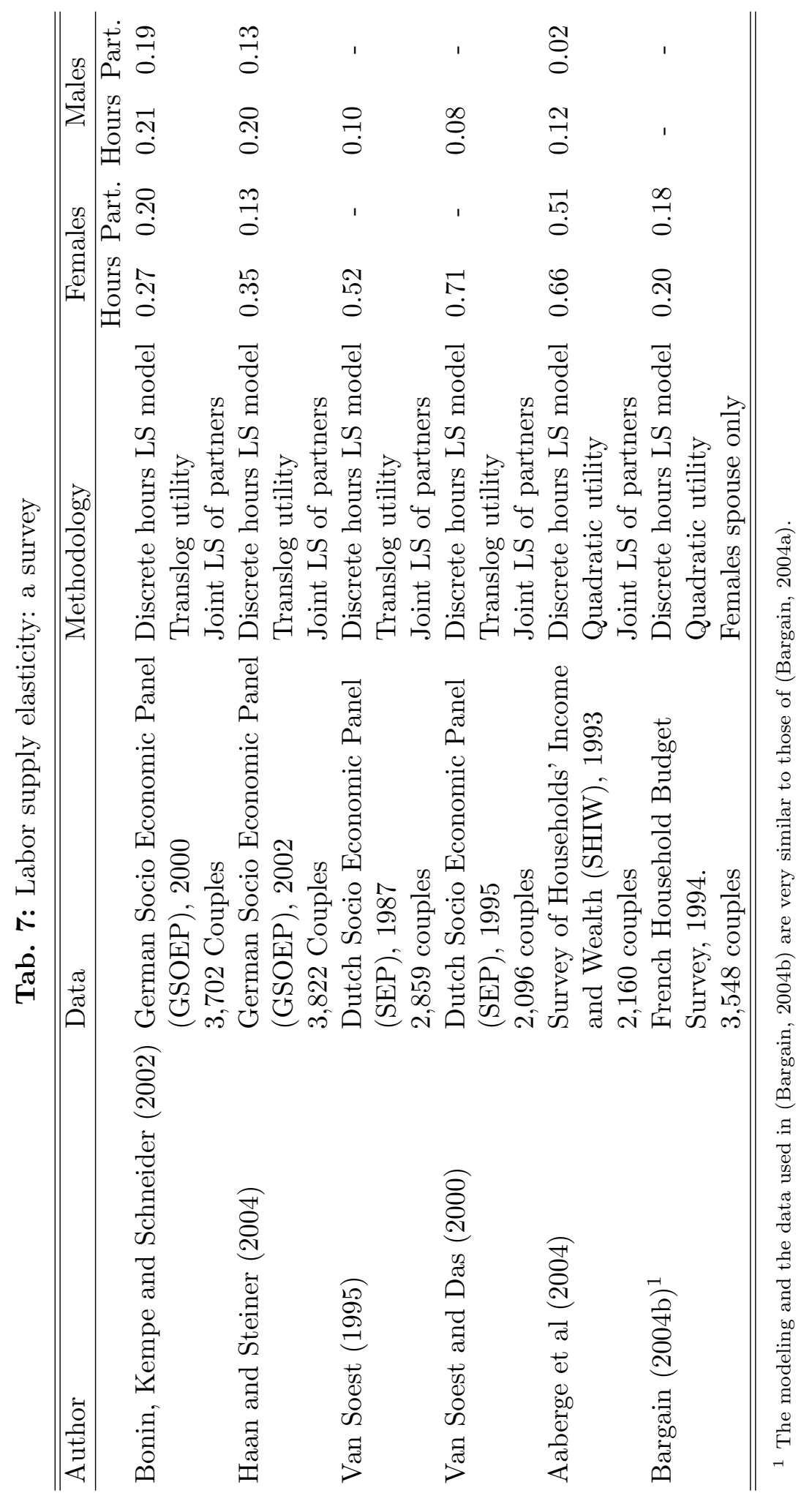




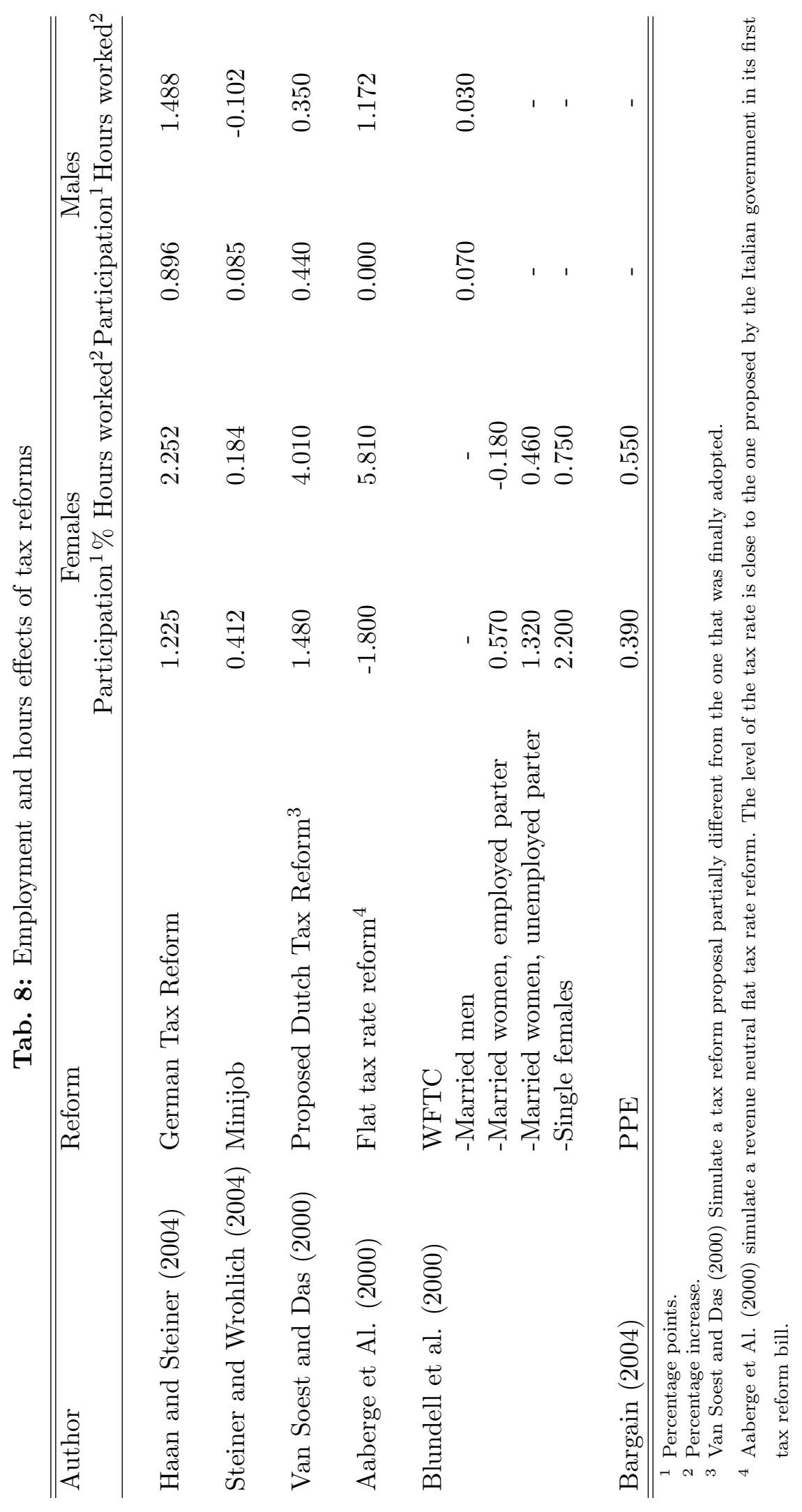




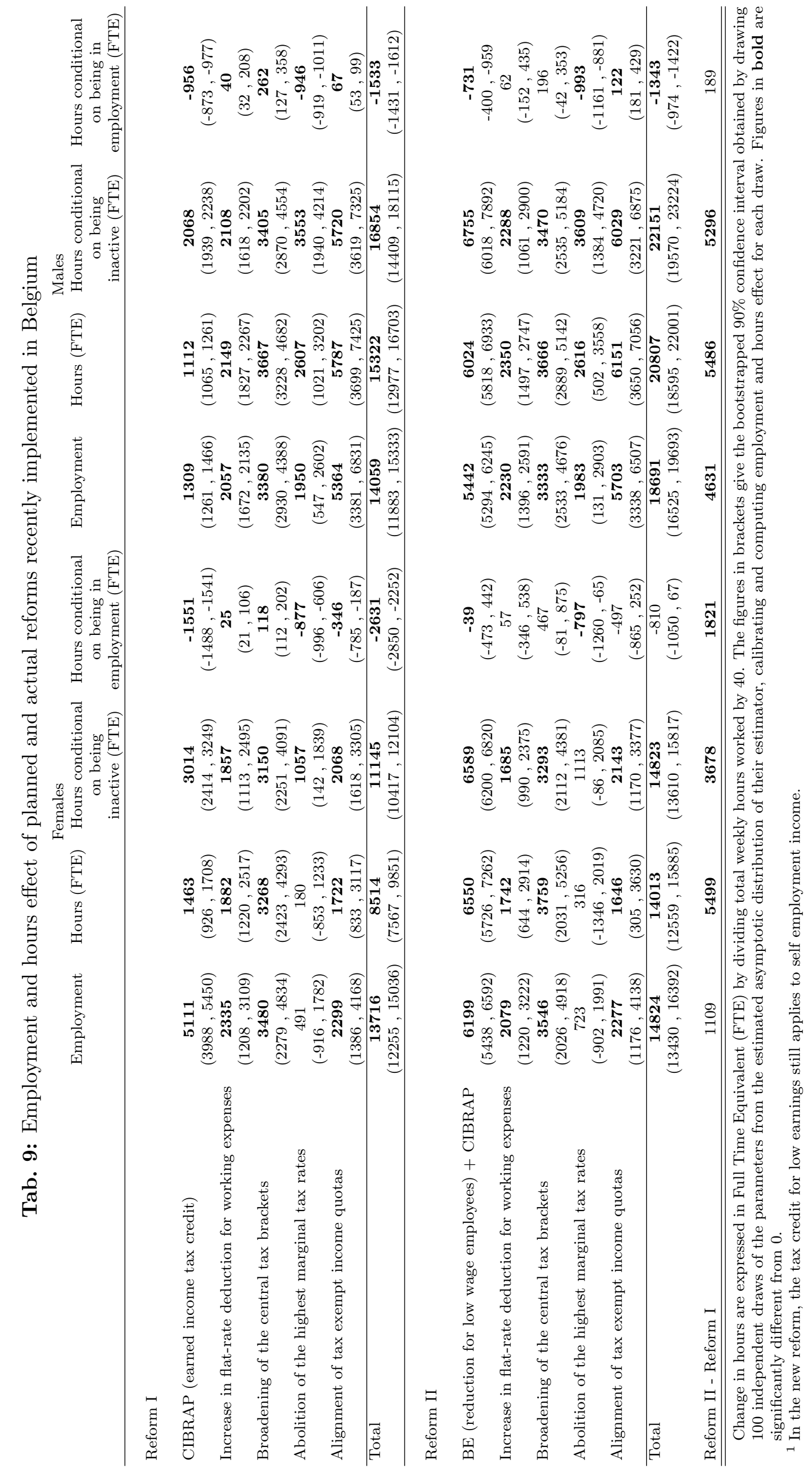


Tab. 10: Budget Cost of Recent Tax and Benefit Reforms

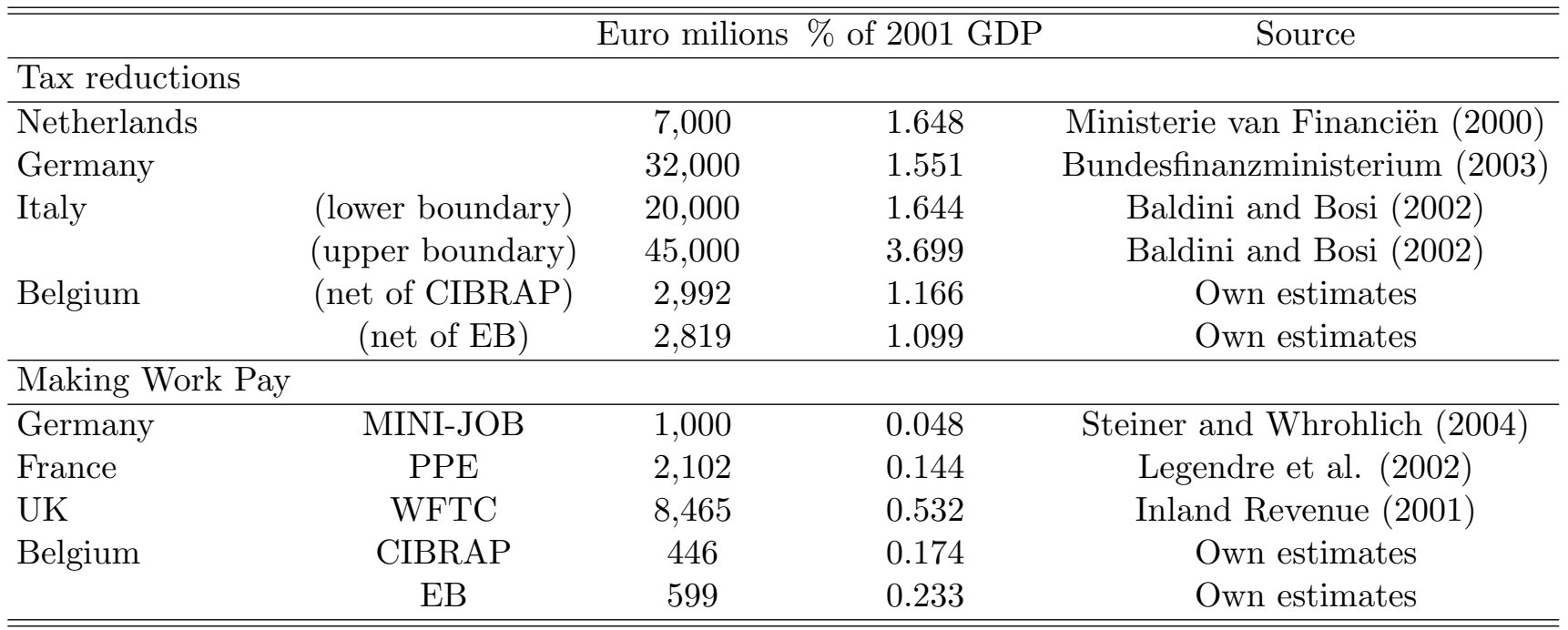

Own estimates are based on Modété. 
Fig. 1: Pre and post reform budget lines for a single earner household ${ }^{1}$
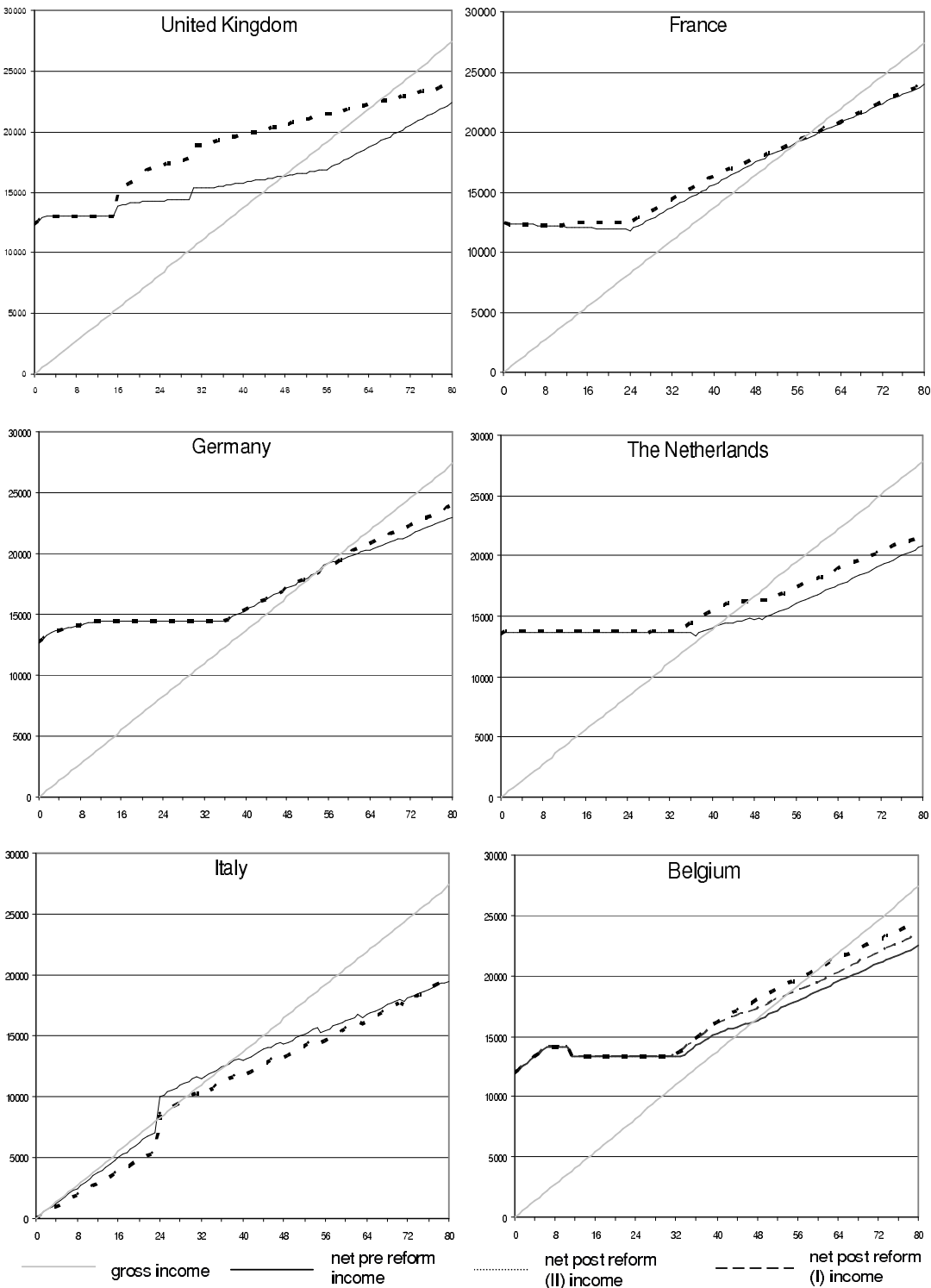

\footnotetext{
${ }^{1}$ Remark: Households with two dependent children (aged 4 and 6), one adult working 0 to 80 at a wage rate of $6.6 \mathrm{EUR} /$ hour

Reform I and Reform II apply to the case of Belgium alone.
} 
Fig. 2: Pre and post reform budget lines for a two earner household ${ }^{1}$
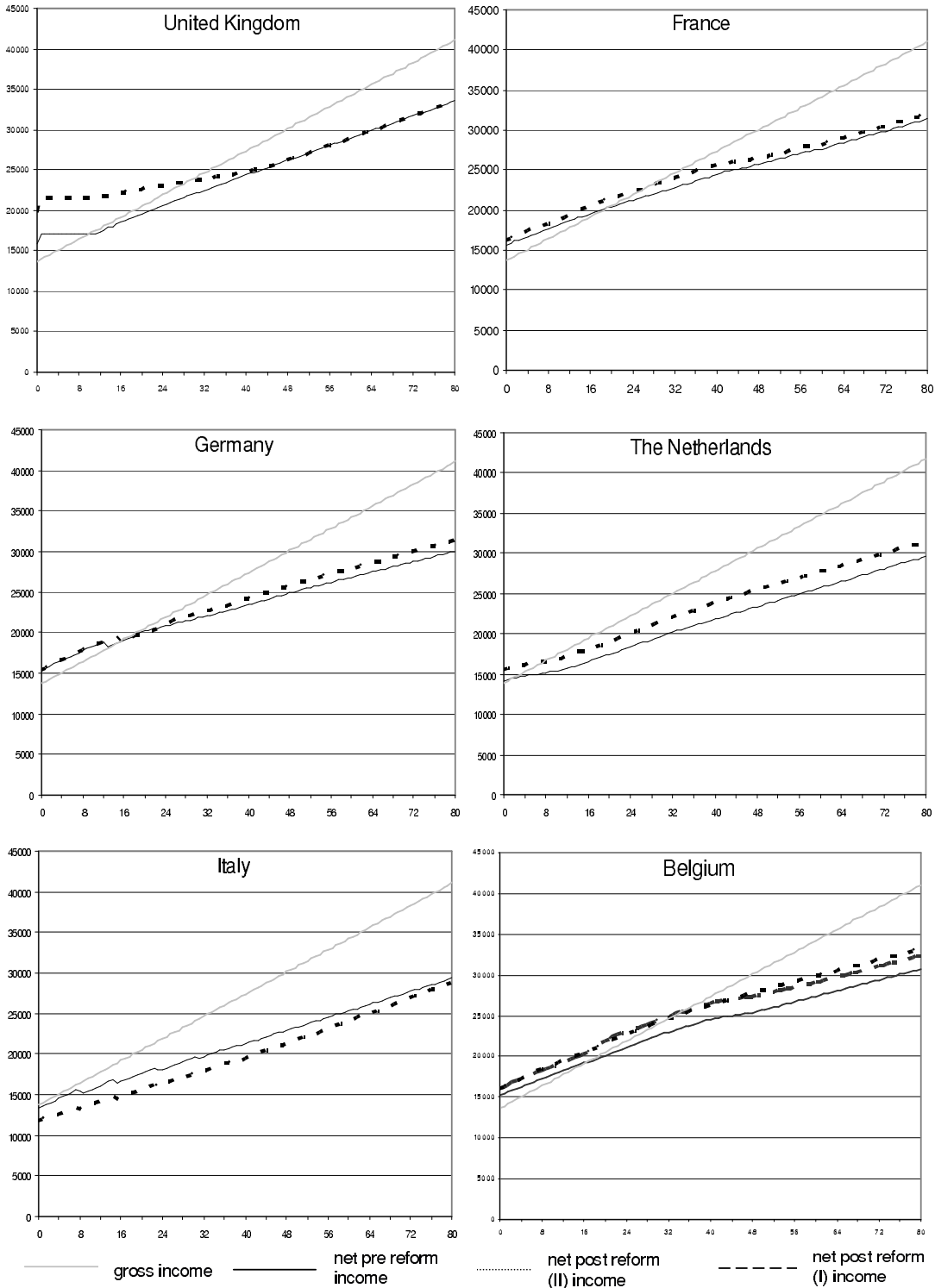

${ }^{1}$ Remark: Households with two dependent children (aged 4 and 6), one partner working 40 hours, the other partner working 0 to 80 both at a wage rate of $6.6 \mathrm{EUR} / \mathrm{hour}$.

Reform I and Reform II apply to the case of Belgium alone. 


\section{References}

Aaberge, R., U. Colombino, and S. Strøm (2004): "Do More Equal Slices Shrink the Cake? An Empirical Investigation of Tax-Transfer Reform Proposals in Italy," Journal of Population Economics, 17, 767-785.

BAldini, M., ANd P. Bosi (2002): "La riforma dell'imposta sul reddito: aspetti di equità ed efficienza," Politica Economica, 3, 303-340.

BARgain, O. (2004a): "Aides au retour à l'emploi et à l'activité des femmes en couple," Revue de l'OFCE, 88, 59-87.

(2004b): "On modelling household labor supply with taxation," DELTA Working Paper, No. 2004-14.

Bargain, O., M. Caliendo, P. HaAn, and K. Orsini (2005): "Making Work Pay' in a Rationed Labour Market: the Mini-Job Reform in Germany," DIW Working Paper, No. 536.

Bargain, O., and K. Orsini (2006): "In-Work Policies in Europe: Killing Two Birds with One Stone," Labour Economics (forthcoming).

Bernardi, L., and P. Profeta (2004): Tax Systems and Tax Reforms in Europe. Routledge, New York.

Blundell, R., M. Brewer, and A. Shephard (2005): "Evaluating the labour market impact of the Working Families' Tax Credit using difference in differences," Inland Revenue Working Paper, No. 4.

Blundell, R., A. Duncan, J. McCrae, and C. Meghir (2000): "The Labour Market impact of the Working Families Tax Credit," Fiscal Studies, 21, 75-104.

Bonin, H., W. Kempe, and H. Schneider (2002): "Household labor supply effects of low-wage subsidies in Germany," IZA Discussion Paper, No. 637.

Bundesfinanzministerium (2003): Tax Reform 2000 - An Overview. Berlin.

Creedy, J., And G. Kalb (2005): "Discrete Hours Labour Supply Modelling: Specification, Estimation and Simulation," Journal of Economic Surveys, 19, 697-734.

Daveri, F., and G. Tabellini (2000): "Unemployment, Growth and Taxation in Industrial Countries," Economic Policy, 15, 47-104.

De Callataÿ, E. (2002): "Réforme et conservatisme - Analyse critique de la réforme de l'impôt des personnes physiques en Belgique," Bulletin de Documentation du Ministère de Finances, 63, 205-215.

De Haan, J., J. E. Sturm, and B. Volkerink (2003): "How to Measure the Tax Burden on Labor at the Macro-Level," CESifo Working Paper, No. 963.

Euwals, R., And A. van Soest (1999): "Desired and actual labour supply of unmarried men and women in the Netherlands," Labour Economics, 6, 95-118.

HaAn, P., And V. Steiner (2004): "Distributional and Fiscal Effects of the German Tax Reform 2000 A Behavioral Microsimulation Analysis," DIW Discussion Paper, No. 418.

Hoynes, H. (1996): "Welfare Transfers in Two Parent Families: Labor Supply and Welfare Participation Under AFDC-UP," Econometrica, 64, 295-332.

Keane, M., and R. Moffit (1998): "A Structural Model of Multiple Welfare Program Participation and Labor Supply," International Economic Review, 39, 553-89. 
Laroque, G., and B. Salanie (2002): "Labour Market Institutions and Employment in France," Journal of Applied Econometrics, 17, 25-48.

Layard, R., And S. Nickell (1999): "Labor Market Institutions and Economic Performance," in Handbook of Labor Economics, Vol. 3A, ed. by O. Ashenfelter, and D. Card, pp. 3029-3086. Elsevier, Amsterdam, North Holland.

Legendre, F., J. P. Lorgnet, R. Mahieu, and F. Thbault (2004): "La prime pour l'emploi constitue-t-elle un instrument de soutien aux bas revenus?," Revue de l'OFCE, 88, 43-58.

McFadden, D. (1973): "Conditional Logit Analysis of Qualitative Choice Behavior," in Frontiers in Econometrics, ed. by P. Zarembka. Academic Press, New York.

Ministerie Van Financiën (2001): Revision of Taxation, 2001. The Hague.

Ministère De Finances (2002): Réforme Fiscale. L'impôt des personnes physiques. Brussels.

Orsini, K. (2005): "The 2001 Belgian Tax Reform: Equity and Efficiency," Ces Discussion Paper no. $05-04$.

Pearson, M., and S. Scarpetta (2000): "An Overview: What Do We Know About Policies to Make Work Pay?," OECD Economic Studies, No. 31, 2000/ii.

PÉRIVIER, H. (2003): "Les mesures fiscales d'incitation au travail des personnes non qualifiées," Revue de l'OFCE, 87, 281-329.

Saintrain, M. (2002): "Effets macro-économiques et budgetaires de la réforme fiscale," Bulletin de Documentation du Ministère de Finances, 63, 129-143.

Steiner, V., and K. Wrohlich (2004): "Household Taxation, Income Splitting and Labour Supply Incentives. A Microsimulation Study for Germany," CESifo Economic Studies, 50, 54168.

(2005): "Work Incentives and Labour Supply Effects of the Mini-Jobs Reform in Germany," Empirica, 32, 91-116.

Sterdyniak, H. (2003): "Les Réformes Fiscales en Europe, 1992-2002," Revue de l'OFCE, 87, $337-407$.

VAllenduc, C. (2002): "La réforme de l'impôt des personnes physiques: ses effets sur l'imposition des salaires, l'incitation à l'emploi et sur la distribution des revenus," Bulletin de Documentation du Ministère de Finances, 63, 145-203.

VAn Soest, A. (1995): "Structural Models of Family Labor Supply: A Discrete Choice Approach," Journal of Human Resources, 30, 63-88.

VAn Soest, A., And M. Das (2000): "Family labor supply and proposed tax reforms in the Netherlands," De Economist, 149, 191-218.

Van Soest, A., M. Das, and X. Gong (2002): "A Structural Labour Supply Model with Flexible Preferences," Journal of Econometrics, 107, 345-374.

Vermeulen, F. (2006): "A collective model for female labour supply with nonparticipation and taxation," Journal of Population Economics (fortcoming).

Wunsch, K. (2003): "Labour Market Policy in Germany: Institutions, Instruments and Reforms since Unification," University of St. Gallen Discussion Paper, No. 2005-06. 
Copyright ( 22006 @ the author(s). Discussion papers are in draft form. This discussion paper is distributed for purposes of comment and discussion only. It may not be reproduced without permission of the copyright holder. Copies of working papers are available from the author. 